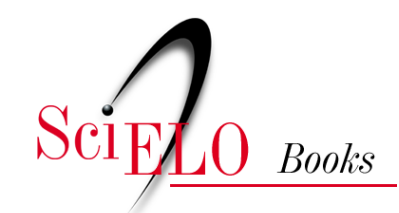

\title{
Parte III - Da proposição à execução ou dos aprendizados da gestão
}

\author{
Silvia Aguião
}

\section{SciELO Books / SciELO Livros / SciELO Libros}

SILVA, A. Da proposição à execução ou dos aprendizados da gestão. In: Fazer-se no "Estado": uma etnografia sobre o processo de constituição dos "LGBT" como sujeitos de direitos no Brasil contemporâneo [online]. Rio de Janeiro: EdUERJ, 2018, pp. 237-239. Sexualidade, gênero e sociedade. Sexualidades e cultura collection. ISBN 978-85-7511-489-6.

https://doi.org/10.7476/9788575115152.0010.

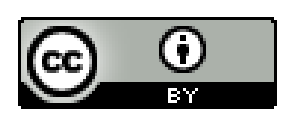

All the contents of this work, except where otherwise noted, is licensed under a Creative Commons Attribution 4.0 International license.

Todo o conteúdo deste trabalho, exceto quando houver ressalva, é publicado sob a licença Creative Commons Atribição $\underline{4.0}$.

Todo el contenido de esta obra, excepto donde se indique lo contrario, está bajo licencia de la licencia $\underline{\text { Creative Commons }}$ Reconocimento 4.0. 


\section{PARTE III DA PROPOSIÇÃO À EXECUÇÃO OU DOS APRENDIZADOS DA GESTÃO}

Esta terceira parte aborda a dimensão local de implantação de uma política voltada para a "população LGBT". Em 2010, fiz a escolha de que um dos focos de atenção privilegiada da pesquisa de campo seria acompanhar uma iniciativa específica no Rio de Janeiro. Dois fatores principais contribuíram para essa escolha. Um deles refere-se à minha proximidade com redes de ativismo e de pesquisadores na cidade, e o outro está relacionado à inauguração de um serviço que, desde antes de sua abertura, vinha sendo divulgado e celebrado como uma espécie de modelo de implementação e gestão de "políticas públicas LGBT".

Em termos metodológicos, a observação detida da implantação de uma política permitiu o acompanhamento de um processo em andamento. De demandas até então pronunciadas em termos de tornar visiveis sujeitos articulados politicamente como uma população específica, passou-se à formulação de propostas de ação, até o ponto em que se constituiu em uma instância governamental na qual essa população precisa ser efetivamente gerida cotidianamente. 
Por meio desse tipo de observação mais detida, encarei a proposta de olhar para o estado como administração pública. Para isso, procurei seguir a proposta de Souza Lima (2002) ancorada no gestar e no gerir, que remetem a funções constitutivas e pedagógicas de coletivos e sua correlata gestão administrativa cotidiana (p. 16). O acompanhamento dos processos de rotinização dos serviços prestados pelo Centro de Referência LGBT do Rio de Janeiro manteve como questionamentos mais amplos: Quais são o papel e a função de um centro de referência? Como é definida a sua "população-alvo"? Quais são as demandas que devem ser enquadradas sob o guarda-chuva da violência relacionada à orientação sexual e/ou identidade de gênero? O cotidiano da administração produz classificações, enquadramentos e disputas a respeito de quem é a autoridade sobre o assunto, imbricados em decisões técnicas e administrativas e estratégias político-simbólicas. Mantendo as questões em perspectiva, procuro descrever a experiência de implantação dessa política específica, enfatizando o envolvimento de uma universidade no referido processo.

Cena 8 - Dia primeiro de julho de dois mil e dez

"Antigamente meu endereço era a delegacia pra ir presa, hoje eu tenho um endereço para nossos problemas, hoje temos nosso espaço. Esse espaço.”

"Um lugar para chamar de seu."

"Acredito que um Centro como esse vai passar a ser copiado em nível nacional por outros estados."

"A militância saiu do público-alvo de pesquisa, objeto de estudo, e mostra que pode propor, desenhar politica e dar pontapé na criação de um novo estado [...]. A sociedade civil deu um passo atrás para aprender com o governo como tornar demandas exequíveis, e o 
governo deu um passo atrás para aprender com o terceiro elemento, que é a sociedade civil.”

"A relação [entre governo e sociedade civil] tem que ser de diálogo e tensão, não é de troca de favores ou do Estado como canal de veiculação da sociedade civil."

"Burocracia é uma máquina de triturar nossos sonhos e esperanças."

“A lei só confirma aquilo que já está acontecendo na sociedade.”

Essas assertivas foram proferidas por diferentes pessoas, inseridas no movimento social e em cargos administrativos de governo, durante a cerimônia de lançamento de um conjunto de serviços lotados num equipamento público do governo estadual do Rio de Janeiro. Os trechos aqui reproduzidos resumem um pouco o tom e as expectativas suscitadas pelo evento.

Os serviços que tiveram a inauguração anunciada em $1^{\circ}$ de julho de 2010 foram:

- Centro de Referência de Promoção da Cidadania LGBT;

- Disque Cidadania LGBT;

- Comissão Processante para o Cumpra-se de Leis Antidiscriminação: Lei 3.406/00, que pune a discriminação contra LGBT, e Lei 3.559/01, que pune a discriminação de pessoas vivendo com HIV/Aids;

- Núcleo de Monitoramento de Crimes contra LGBT;

- Núcleo do Programa Rio Sem Homofobia;

- Centro de Documentação e Informação LGBT;

- Conselho Estadual dos Direitos da População LGBT;

- Centro de Referência de Promoção da Liberdade Religiosa e Contra a Intolerância, defesa e apoio jurídico, psicológico e social; 
- Centro de Referência de Promoção dos Direitos Humanos em DST/Aids e outras doenças, defesa e apoio jurídico, psicológico e social;

- Centro de Formação de Cidadania e Diversidades. 